\title{
Molecular Characterization of Bovine CSN1S2*B and Extensive Distribution of Zebu-Specific Milk Protein Alleles in European Cattle
}

\author{
E. M. Ibeagha-Awemu, ${ }^{\star} \dagger$ E.-M. Prinzenberg, ${ }^{*}$ O. C. Jann, ${ }^{*}$ G. Lühken, ${ }^{*}$ A. E. Ibeagha, $\dagger$ \\ X. Zhao, $†$ and G. Erhardt ${ }^{\star 1}$ \\ *Institute of Animal Breeding and Genetics, Justus-Liebig-University, Ludwigstrasse 21b, D-35390 Giessen, Germany \\ †Department of Animal Science, Macdonald Campus of McGill University, Ste-Anne-de-Bellevue, Quebec, H9X 3V9, Canada
}

\begin{abstract}
The $B$ allele of the bovine $\alpha_{\mathrm{S} 2}$-casein gene (CSN1S2) was characterized at the molecular level and the distribution of zebu-specific milk protein alleles was determined in 26 cattle breeds originating from 3 continents. The $C S N 1 S 2{ }^{*} B$ allele is characterized by a $\mathrm{C} \rightarrow \mathrm{T}$ transition affecting nucleotide 17 of exon 3 , which leads to a change in the eighth amino acid of the mature protein, from Ser to Phe (i.e., TCC $\rightarrow$ TTC). DNA-based methods were developed to identify carriers of $C S N 1 S 2 * B$ and the other alleles $(C S N 1 S 2 * A, C$, and $D)$ at the same locus. CSN1S2*B and other zebu-specific milk protein alleles and casein haplotypes are widely distributed in European cattle breeds, particularly those of southeastern origin. Alleles $C S N 1 S 2 * B$ and $C S N 3 * H$ are important in searching for zebu imprints in European cattle breeds. Diversity estimates at the milk protein loci were highest in the zebus followed by southeastern European taurines. Anatolian Black had the highest number of zebu alleles among European taurines. Common, group, and intergroup haplotypes occurred in the breeds and demonstrated relationships that concurred with developmental histories, genetic makeup, and, in particular, exposed the extent of zebu influence on southeastern European cattle.
\end{abstract}

Key words: $\alpha_{\mathrm{S} 2}$-casein, zebu-specific alleles, Bos, haplotypes

\section{INTRODUCTION}

The $\alpha_{\mathrm{S}_{2}}-\mathrm{CN}$ gene (CSN1S2), a member of the CN gene family, codes for $\alpha_{\mathrm{S} 2}-\mathrm{CN}$ (CSN1S2), which constitutes up to $10 \%$ of the bovine $\mathrm{CN}$ fraction and exists in 2 major forms and several minor components. The reference protein form, CSN1S2*A, is a single polypeptide of 207 AA. Its sequence was originally determined

Received October 17, 2006.

Accepted February 14, 2007.

${ }^{1}$ Corresponding author: georg.erhardt@agrar.uni-giessen.de chemically (Brignon et al., 1977) and later by cDNA and genomic DNA sequencing (Stewart et al., 1987; Groenen et al., 1993). In addition to CSN1S2*A, 3 other protein variants $(\mathrm{B}, \mathrm{C}$, and $\mathrm{D})$ are known. Variants $\mathrm{B}$ and $\mathrm{C}$ are specific to zebu and yaks, respectively (Grosclaude et al., 1976, 1978, 1982), whereas the D variant has been found at low frequencies in some European breeds and the African Namchi taurine breed (Grosclaude et al., 1979; Erhardt, 1993; Jann et al., 2004; Ibeagha-Awemu et al., 2005a). The original variant $\mathrm{A}$ is the most frequent in all breeds so far investigated and also almost fixed in most western breeds. The different forms of the gene and protein are caused by single nucleotide polymorphisms (SNP) that result in amino acid changes. Single nucleotide polymorphisms in the CSN1S $2 * \mathrm{C}$ protein result in AA changes at positions 33 (Glu to Gly), 47 (Ala to Thr), and 130 (Thr to Ile) compared with the A variant (Mahé and Grosclaude, 1982). Although CSN1S2*D differs from CSN1S2*A by the splicing-out of exon 8 (AA residues 51 to 59) due to an SNP in the genomic DNA sequence, the distinguishing feature(s) of $\mathrm{CSN} 1 \mathrm{~S} 2 * \mathrm{~B}$ variant have not yet been determined. In a recent analysis of African zebu cattle, Ibeagha-Awemu et al. (2005b) recorded CSN1S2*B at frequencies of 3 to $20 \%$. Considering that this variant is also prevalent in other breed groups; for example, the Podolic cattle of Italy (Chianese et al., 1988), detailed information about its nature and distribution are therefore necessary.

Similar to the observation of CSN1S2*B in the Italian Podolic breed, other zebu-specific milk protein alleles and $\mathrm{CN}$ haplotypes have been reported in southeastern European breeds (Prinzenberg et al., 1999; Jann et al., 2004). Because some milk protein variants, like CSN1S2*B and LAA*A, were believed to exist in zebu breeds only, they are often ignored in milk protein studies of European cattle (Formaggioni et al., 1999). The extent of their occurrence and distribution in European cattle breeds is therefore poorly understood.

Alleles that display a higher or exclusive presence in zebus while showing a relatively low presence or complete absence in the other Bos species are denoted 
as zebu-specific alleles. Differences in allelic distributions can be used to assess the ancestry of populations or to determine relationships between different gene pools; this approach is similar to the concept of population-associated alleles defined by Kumar et al. (2003). MacHugh et al. (1997) first applied this concept to cattle populations. Subsequent investigations have expanded the list, including milk protein alleles and haplotypes, mitochondrial DNA haplotypes, and microsatellite alleles (Loftus et al., 1999; Mahé et al., 1999; MoazamiGoudarzi et al., 2001; Troy et al., 2001; Ceriotti et al., 2004; Cymbron et al., 2005; Ibeagha-Awemu et al., 2005a) and confirmed their usefulness in the study of genetic relationships between the Bos species. This approach thus contributes supportive molecular evidence, in addition to information from sex chromosomal analysis (Hanotte et al., 2000), necessary to substantiate historical and archeological claims of earlier and more recent contacts between zebu and European taurine cattle after their initial separation. Zebu-specific attributes may be more widely distributed in European cattle than suggested by current data.

The aims of the study were to characterize the CSN1S2*B protein variant at the molecular level and to determine its distribution and that of other zebu milk protein alleles in Bos taurus breeds.

\section{MATERIALS AND METHODS}

\section{Sampled Breeds and Genes}

A total of 1,185 unrelated individuals bearing typical breed characteristics of 26 breeds from 10 countries spanning 3 continents were sampled for the study (Table 1). The breed groups include Indian zebu, African zebu, African taurine, and European taurine. Nelore and Brahman were recently imported into Brazil and Paraguay from India and are here considered as representations of Indian zebu genes. DNA was isolated from the blood of sampled animals according to the method of Montgomery and Sise (1990). Samples carrying the CSN1S2*B variant were selected for characterization at the DNA level. Specific zebu alleles at other milk protein loci $\left[\alpha_{\mathrm{S} 1}-\mathrm{CN}\right.$ promoter (CSN1S1Prom), $\kappa$-CN (CSN3), and $\alpha$-LA $(L A A)]$ were also genotyped. The $\alpha_{\mathrm{S}^{-}}$ $\mathrm{CN}(C S N 1 S 1)$ and $\beta$-CN (CSN2) genes were also included.

\section{Sequence Characterization of CSN1S2*B}

Several primer pairs were designed to amplify the open reading frame of the cattle CSN1S2 gene (GenBank No. M94327; Groenen et al., 1993), including exons 2 to 16 (Table 2). These sections in 3 individuals of the Banyo Gudali breed (2 homozygous and 1 heterozy- gous for the $B$ allele; Ibeagha-Awemu et al., 2005b) were PCR amplified and analyzed for polymorphisms by sequencing. The PCR amplifications with their respective primers (Table 2) were carried out in a $20-\mu \mathrm{L}$ reaction volume containing $50 \mathrm{ng}$ of genomic DNA, $1 \times$ PCR buffer ( $50 \mathrm{~m} M \mathrm{KCl}, 10 \mathrm{~m} M$ Tris-HCl, $\mathrm{pH}$ 8.3), 1.5 to $2.5 \mathrm{mM} \mathrm{MgCl}$ (Table 2), $200 \mu M$ dNTP, 10 pmol of each primer, and 0.5 to $2 \mathrm{U}$ of Taq DNA polymerase (Eppendorf AG, Hamburg, Germany). The cycling conditions using the BioRad thermal iCycler (BioRad Laboratories $\mathrm{GmbH}$, München, Germany) included an initial denaturation at $94^{\circ} \mathrm{C}$ for 2 min followed by 30 cycles each of $94^{\circ} \mathrm{C}$ for $30 \mathrm{~s}, 53.7$ to $62.5^{\circ} \mathrm{C}$ (Table 2 ) for $1 \mathrm{~min}$, $72^{\circ} \mathrm{C}$ for 40 to $75 \mathrm{~s}$ (depending on size of fragment), and a final extension step at $72^{\circ} \mathrm{C}$ for $5 \mathrm{~min}$. Before sequencing, the PCR products were purified using the Wizard SV Gel and PCR Clean-Up-System (Promega $\mathrm{GmbH}$, Mannheim, Germany). Both sides of purified PCR products were sequenced using the big dye termination technique and an ABI Prism 377 DNA sequencer (Applied Biosystems, Foster City, CA) following the manufacturer's instructions. The sequences were processed with Chromas Version 1.45 (http://www.technelysium.com.au/chromas.html) and compared with the sequence of the bovine CSN1S2*A gene (GenBank No. M94327) with GeneDoc (Nicholas and Nikolas, 1997; http://www.psc.edu/biomed/genedoc).

\section{Genotyping of Alleles at the CSN1S2 Locus $(A, B, C$, and $D)$}

Based on the sequence characteristics of the alleles, methods employing restriction enzymes were developed to identify their presence. For $\operatorname{CSN} 1 S 1^{*} B$, a 253-bp region encompassing an SNP characterizing the $B$ variant was PCR amplified using the primers B $\alpha$ S2_6090F and $\mathrm{B} \alpha \mathrm{S} 2 \_6342 \mathrm{R}$ (Table 2). The $15-\mu \mathrm{L}$ PCR reaction contained $50 \mathrm{ng}$ of genomic DNA, 1× PCR buffer (50 $\mathrm{m} M \mathrm{KCl}, 10 \mathrm{~m} M$ Tris- $\mathrm{HCl}, \mathrm{pH} 8.3$, and $1.5 \mathrm{~m} M \mathrm{MgCl}_{2}$ ), $200 \mu M$ dNTP, 10 pmol of each primer, and $0.35 \mathrm{U}$ of Taq DNA polymerase (Eppendorf AG). The PCR was performed in an iCycler (BioRad Laboratories $\mathrm{GmbH}$ ) with the following conditions: initial denaturation for 2 min at $94^{\circ} \mathrm{C}$ followed by 30 cycles each of $30 \mathrm{~s}$ at $94^{\circ} \mathrm{C}$ (denaturation), $30 \mathrm{~s}$ at $59.3^{\circ} \mathrm{C}$ (annealing), and $1 \mathrm{~min}$ at $72^{\circ} \mathrm{C}$ (elongation), and a final extension for $10 \mathrm{~min}$ at $72^{\circ} \mathrm{C}$. Amplified products were digested with 1 unit of $\mathrm{MboII}$ enzyme for $16 \mathrm{~h}$ at $37^{\circ} \mathrm{C}$.

For alleles $C$ and $D$, primers were designed to contain the respective characteristic mutations in exon 6 $\left(\mathrm{Glu}_{33} \rightarrow \mathrm{Gly}_{33}\right.$; i.e., GAG $\left.\rightarrow \mathrm{GGG}\right)$ and $8\left(\mathrm{G}_{8879} \rightarrow \mathrm{T}_{8879}\right.$, last nucleotide of exon) of GenBank No. M94327. A 459-bp region was PCR amplified with the primers $\mathrm{B} \alpha \mathrm{S} 2 \_7360 \mathrm{~F}$ and $\mathrm{B} \alpha \mathrm{S} 2 \_7818 \mathrm{R}$ for the $C$ allele and a 
Table 1. Breeds, origin, and genetic diversity estimates

\begin{tabular}{lllllc}
\hline Breed group & \multicolumn{1}{c}{ Breed name } & Acronym & Country & $\mathrm{n}$ & $\mathrm{He}^{1}$ \\
\hline Indian zebu & Brahman & BR & Paraguay & 50 & 0.452 \\
& Nelore & NE & Brazil & 50 & 0.400 \\
African zebu & Adamawa Gudali & AG & Nigeria & 11 & 0.504 \\
& Banyo Gudali & BG & Cameroon & 77 & 0.474 \\
& Cameronian Red Bororo & CRB & Cameroon & 52 & 0.483 \\
& Cameronian White Fulani & CWF & Cameroon & 44 & 0.473 \\
& Ngaoundere Gudali & NG & Cameroon & 55 & 0.385 \\
& Nigerian Red Bororo & NRB & Nigeria & 52 & 0.475 \\
& Nigerian White Fulani & NWF & Nigeria & 53 & 0.490 \\
& Sokoto Gudali & SG & Nigeria & 65 & 0.481 \\
African taurine & Wadara & WA & Nigeria & 36 & 0.480 \\
& Muturu & MU & Nigeria & 19 & 0.236 \\
Southeastern European taurine & Namchi & NA & Cameroon & 30 & 0.427 \\
& N'Dama & ND & Nigeria & 26 & 0.214 \\
& Chianina & AB & Turkey & 50 & 0.433 \\
& Piemontese & PIM & Italy & 50 & 0.348 \\
& Turkish Gray Steppe & TGS & Turkey & 50 & 0.398 \\
Central European taurine & British Friesian & BF & United Kingdom & 51 & 0.457 \\
& Charolais & CHA & France & 56 & 0.295 \\
& German Angus & GA & Germany & 54 & 0.305 \\
& German Red & GR & Germany & 30 & 0.251 \\
& German Simmental & GS & Germany & 40 & 0.283 \\
& German Yellow & GY & Germany & 36 & 0.280 \\
& Jersey & JE & United Kingdom & 48 & 0.353 \\
& Polish Red & PR & Poland & 50 & 0.340
\end{tabular}

${ }^{1} \mathrm{He}=$ gene diversity, calculated with the genotype information at all loci typed (CSN1S1Prom, CSN1S1, CSN1S2, CSN2, CSN3, and LAA).

Table 2. Primers and conditions for PCR amplification of the CSN1S2 open reading frame and genotyping

\begin{tabular}{|c|c|c|c|c|}
\hline Exon & $\begin{array}{l}\text { Primer } \\
\text { name }^{1}\end{array}$ & $\begin{array}{l}\text { Primer sequences } \\
\text { (forward and reverse) }\end{array}$ & $\begin{array}{l}\text { Size, } \\
\text { bp }\end{array}$ & $\begin{array}{c}\text { Annealing } \\
\text { temperature and } \\
\mathrm{MgCl}_{2} \text { concentration }\end{array}$ \\
\hline 2 & $\begin{array}{l}\mathrm{B} \alpha \mathrm{S} 2 \_4220 \mathrm{~F} \\
\mathrm{~B} \alpha \mathrm{S} 2 \_4560 \mathrm{R}\end{array}$ & $\begin{array}{l}5^{\prime} \text { TCAGTCTTCATTGCCCTTTTC } 3^{\prime} \\
5^{\prime} \text { TTACATAAGGCAGGGCCAAG } 3^{\prime}\end{array}$ & 341 & $53.7^{\circ} \mathrm{C}, 1.5 \mathrm{~m} M$ \\
\hline $3,4,5$ & $\begin{array}{l}\mathrm{B} \alpha \mathrm{S} 2 \_6090 \mathrm{~F} \\
\mathrm{~B} \alpha \mathrm{S} 2 \_7378 \mathrm{R}\end{array}$ & $\begin{array}{l}5^{\prime} \text { CCTAAAAGTCTCTTGCCATC } 3^{\prime} \\
5^{\prime} \text { GTGGCTCAAAAATGGCTCTC } 3^{\prime}\end{array}$ & 1,289 & $62.5^{\circ} \mathrm{C}, 2.5 \mathrm{mM}$ \\
\hline $6,7,8$ & $\begin{array}{l}\mathrm{B} \alpha \mathrm{S} 2 \_7565 \mathrm{~F} \\
\mathrm{~B} \alpha \mathrm{S} 2 \_8979 \mathrm{R}\end{array}$ & $\begin{array}{l}5^{\prime} \text { AGGAGAACCTTTGCTCCACA } 3^{\prime} \\
5^{\prime} \text { GCTCACCCTATTTGCGATGT 3' }\end{array}$ & 1,415 & $52^{\circ} \mathrm{C}, 1.5 \mathrm{~m} M$ \\
\hline 9,10 & $\begin{array}{l}\mathrm{B} \alpha \mathrm{S} 2 \_8960 \mathrm{~F} \\
\mathrm{~B} \alpha \mathrm{S} 2 \_10156 \mathrm{R}\end{array}$ & $\begin{array}{l}5^{\prime} \text { ACATCGCAAATAGGGTGAGC } 3^{\prime} \\
5^{\prime} \text { TGAACATTCGAGGAGAAGCA } 3^{\prime}\end{array}$ & 1,197 & $55^{\circ} \mathrm{C}, 1.5 \mathrm{~m} M$ \\
\hline 11,12 & $\begin{array}{l}\mathrm{B} \alpha \mathrm{S} 2 \_10137 \mathrm{~F} \\
\mathrm{~B} \alpha \mathrm{S} 2 \_11213 \mathrm{R}\end{array}$ & $\begin{array}{l}5^{\prime} \text { TGCTTCTCCTCGAATGTTCA } 3^{\prime} \\
5^{\prime} \text { GCCTTCCCCAGATTTTTCTT 3' }\end{array}$ & 1,077 & $56^{\circ} \mathrm{C}, 2.0 \mathrm{~m} M$ \\
\hline 13 & $\begin{array}{l}\mathrm{B} \alpha \mathrm{S} 2 \_12266 \mathrm{~F} \\
\mathrm{~B} \alpha \mathrm{S} 2 \_12597 \mathrm{R}\end{array}$ & $\begin{array}{l}5^{\prime} \text { AGACTCTTGGGATACAACGTGA } 3^{\prime} \\
5^{\prime} \text { GAGGAACAGAGTTAAGTGCTGGA } 3^{\prime}\end{array}$ & 332 & $61.5^{\circ} \mathrm{C}, 2 \mathrm{~m} M$ \\
\hline 14,15 & $\begin{array}{l}\mathrm{B} \alpha \mathrm{S} 2 \_13825 \mathrm{~F} \\
\mathrm{~B} \alpha \mathrm{S} 2 \_14502 \mathrm{R}\end{array}$ & $\begin{array}{l}5^{\prime} \text { ACTCCCTTGCTTTGCATCTG } 3^{\prime} \\
5^{\prime} \text { GGGTGGATACGTGGCAATAG 3' }\end{array}$ & 678 & $56.3^{\circ} \mathrm{C}, 2 \mathrm{~m} M$ \\
\hline 16 & $\begin{array}{l}\mathrm{B} \alpha \mathrm{S} 2 \_15143 \mathrm{~F} \\
\mathrm{~B} \alpha \mathrm{S} 2 \_15739 \mathrm{R}\end{array}$ & $\begin{array}{l}5^{\prime} \text { CCCCTTGCCTTCTTACACAA 3' } \\
5^{\prime} \text { CCATGGCAAGCACAATGTAT } 3^{\prime}\end{array}$ & 597 & $56.2^{\circ} \mathrm{C}, 2 \mathrm{~m} M$ \\
\hline $\begin{array}{l}\text { Allele } \\
B\end{array}$ & $\begin{array}{l}\mathrm{B} \alpha \mathrm{S} 2 \_6090 \mathrm{~F} \\
\mathrm{~B} \alpha \mathrm{S} 2 \_6342 \mathrm{R}\end{array}$ & $\begin{array}{l}5^{\prime} \text { CCTAAAAGTCTCTTGCCATC } 3^{\prime} \\
5^{\prime} \text { ACAGTTCTAGACTCACTGGAGA } 3^{\prime}\end{array}$ & 253 & $59.3^{\circ} \mathrm{C}, 1.5 \mathrm{~m} M$ \\
\hline C & $\begin{array}{l}\mathrm{B} \alpha \mathrm{S} 2 \_7360 \mathrm{~F} \\
\mathrm{~B} \alpha \mathrm{S} 2 \_7818 \mathrm{R}\end{array}$ & $\begin{array}{l}5^{\prime} \text { AGAGCCATTTTTGAGCCACA } 3^{\prime} \\
5^{\prime} \text { CTGGGAATCAAATGTGTTAG } 3^{\prime}\end{array}$ & 459 & $53.7^{\circ} \mathrm{C}, 1.5 \mathrm{~m} M$ \\
\hline$D$ & $\begin{array}{l}\mathrm{B} \alpha \mathrm{S} 2 \_8675 \mathrm{~F} \\
\mathrm{~B} \alpha \mathrm{S} 2 \_9030 \mathrm{R}\end{array}$ & $\begin{array}{l}5^{\prime} \text { AAAACAAGCAGCCAAGAAGC } 3^{\prime} \\
5^{\prime} \text { TTCCCAGTCTCCCCAGTATG } 3^{\prime}\end{array}$ & 356 & $60.5^{\circ} \mathrm{C}, 1.5 \mathrm{~m} M$ \\
\hline
\end{tabular}

${ }^{1}$ Primer names are based on their positions on the reference sequence, GenBank No. M94327. 
356-bp region was amplified with the primers $\mathrm{B} \alpha \mathrm{S} 2 \_8675 \mathrm{~F}$ and $\mathrm{B} \alpha \mathrm{S} 2 \_9030 \mathrm{R}$ for the $D$ allele (Table 2 ). In both cases, the $P C R$ reaction was in a final volume of $15 \mu \mathrm{L}$ containing $50 \mathrm{ng}$ of DNA, $1 \times$ PCR buffer (50 $\mathrm{m} M \mathrm{KCl}, 10 \mathrm{~m} M$ Tris-HCl, $\mathrm{pH} 8.3$, and $1.5 \mathrm{~m} M \mathrm{MgCl}_{2}$ ), $200 \mu M$ dNTP, 10 pmol of each primer, and $0.35 \mathrm{U}$ of Taq DNA polymerase (Eppendorf AG). The thermal profile (iCycler) included an initial denaturation for 2 min at $94^{\circ} \mathrm{C}$ followed by 30 cycles each of denaturation for $30 \mathrm{~s}$ at $94^{\circ} \mathrm{C}$, annealing for $30 \mathrm{~s}$ at 53.7 or $60.5^{\circ} \mathrm{C}$ (Table 2), and elongation for $30 \mathrm{~s}$ at $72^{\circ} \mathrm{C}$, and a final elongation for $10 \mathrm{~min}$ at $72^{\circ} \mathrm{C}$. The resulting products were digested with 1 unit of NlaIV enzyme (allele $C$ ) or $\mathrm{MnlI}$ enzyme (allele $D$ ) for $16 \mathrm{~h}$ at $37^{\circ} \mathrm{C}$. The resulting fragments were separated in $1 \%$ agarose gels and visualized by fluorescent absorption under UV radiation. The presence of the $C$ allele was investigated in at least 20 random individuals of each breed homozygous for the $A$ allele to exclude its occurrence in the studied breeds. Yak and German Red individuals heterozygous, respectively, for the $\mathrm{C}$ and $\mathrm{D}$ protein variants were used as standards (Erhardt, 1993).

\section{Genotyping of Alleles at Other Milk Protein Loci}

The methods of PCR-single strand conformation polymorphism (Prinzenberg et al., 2003) and PCR-RFLP (Mitra et al., 1998) were used to genotype alleles at CSN1S1Prom (alleles 1 to 5) and $L A A$ (alleles $A$ and $B$ ), respectively. Genes $C S N 1 S 1, C S N 2$, and $C S N 3$ were genotyped by isoelectric focusing and PCR-single strand conformation polymorphism (Erhardt, 1993; Barroso et al., 1999; Prinzenberg et al., 1999).

\section{Statistical Analysis}

Allele frequencies at the loci studied were estimated with the GENEPOP program (Raymond and Rousset, 2001) and gene diversities (or expected unbiased heterozygosities) with the POPGENE program (version 1.31; Yeh et al., 1999). Haplotypes at the $4 \mathrm{CN}$ loci, including the promoter region of CSN1S1 were determined with the program PHASE V2.1.1 (Stephens et al., 2001; Stephens and Donnelly, 2003). The PHASE program implements a Bayesian method of haplotype reconstruction based on genealogies reconstructed from coalescent theory under a Markov chain Monte Carlo framework and has been shown to outperform other strategies in most cases (Stephens et al., 2001).

\section{RESULTS}

Comparison of the sequenced regions of CSN1S2*B with $C S N 1 S 2 * A$ (GenBank No. M94327) showed a sin- gle $\mathrm{C} \rightarrow \mathrm{T}$ transition at nucleotide 17 in exon 3 . This SNP changes the eighth AA of the mature protein, Ser $_{8-}$ $\rightarrow \mathrm{Phe}_{8}$ (TCC $\rightarrow$ TTC) and also creates a restriction site for $M b o I I$ restriction endonucleases, enabling identification of $C S N 1 S 2 * B$ by RFLP. The MboII enzyme cuts the amplified 253-bp region, including exon 3, into 2 fragments of 126 and $127 \mathrm{bp}$ for the $B$ allele, whereas all other alleles remain uncut (data not shown).

Previously described mutations within the $D$ and $C$ variants also affected restriction sites and enabled their detection by restriction enzymes. For the $\operatorname{CSN} 1 S 2 * D$ allele, the recognition site of $M n l \mathrm{I}$ was disrupted by the SNP, resulting in an uncut 356-bp amplified product, whereas $\operatorname{CSN} 1 S 2 * A$ and other alleles were cut into 2 fragments of 160 and $196 \mathrm{bp}$. The exon 6 mutation in CSN $1 S 2 * C$ created a restriction site for NlaIV, which cut the amplified 459-bp region into fragments (211 and $248 \mathrm{bp}$ ) whereas other alleles remained uncut.

The distribution of these CSN1S2 alleles and alleles at the CSN1S1Prom, CSN3, and LAA loci in the breeds studied is shown in Table 3 and indicates the presence of zebu-specific milk protein alleles in European breeds. Frequencies of $C S N 1 S 2 * B$ and $L A A^{*} A$ were higher in Nelore and Brahman than the African zebus and were also found with low frequencies in 6 European taurine breeds and 1 African taurine breed. The combined frequencies of alleles $A_{1}$ and $H$ of $C S N 3$ were greatest in Brahman and Nelore, followed by the African zebus. Within the taurines, $\operatorname{CSN} 3 * A_{1}$ was only detected in Anatolian Black and Namchi, whereas $C S N 3^{*} H$ was more widely distributed, with frequencies as high as 0.353 in Anatolian Black and 0.344 in the Turkish Gray Steppe. Zebu-specific allele 5 of CSN1S1Prom was more frequent in the African zebus than in the Indian zebu representatives; Chianina was the only European breed with this allele.

Genotypes at CSN1S1 and CSN2 were included in gene diversity analysis because one allele each at these loci occurred at frequencies above 50\% in zebu breeds. Gene diversity estimates were higher in the zebus, southeastern European breeds, and the Cameroonian Namchi (taurine) than in other breed groups (Table 1).

Using genotypes of the 22 alleles detected at these loci; the PHASE program determined a total of $252 \mathrm{CN}$ haplotypes (CSN1S1Prom-CSN1S1-CSN1S2-CSN2CSN3; data not shown). Only those haplotypes that occurred at frequencies $>0.01$ will be further reported. Our analysis showed haplotypes that were common to all breeds, specific to particular breed groups, or shared between certain groups (Figure 1), and further explains zebu influence on European cattle. Group-specific haplotypes were either completely absent or occurred at frequencies $<0.01$ in the other groups. The haplotype $2 B A A^{2} B \quad$ (CSN1S1Prom*2-CSN1S1*B-CSN1S2*A- 
Table 3. Alleles and frequencies at 4 milk protein loci showing zebu-specific alleles (bold)

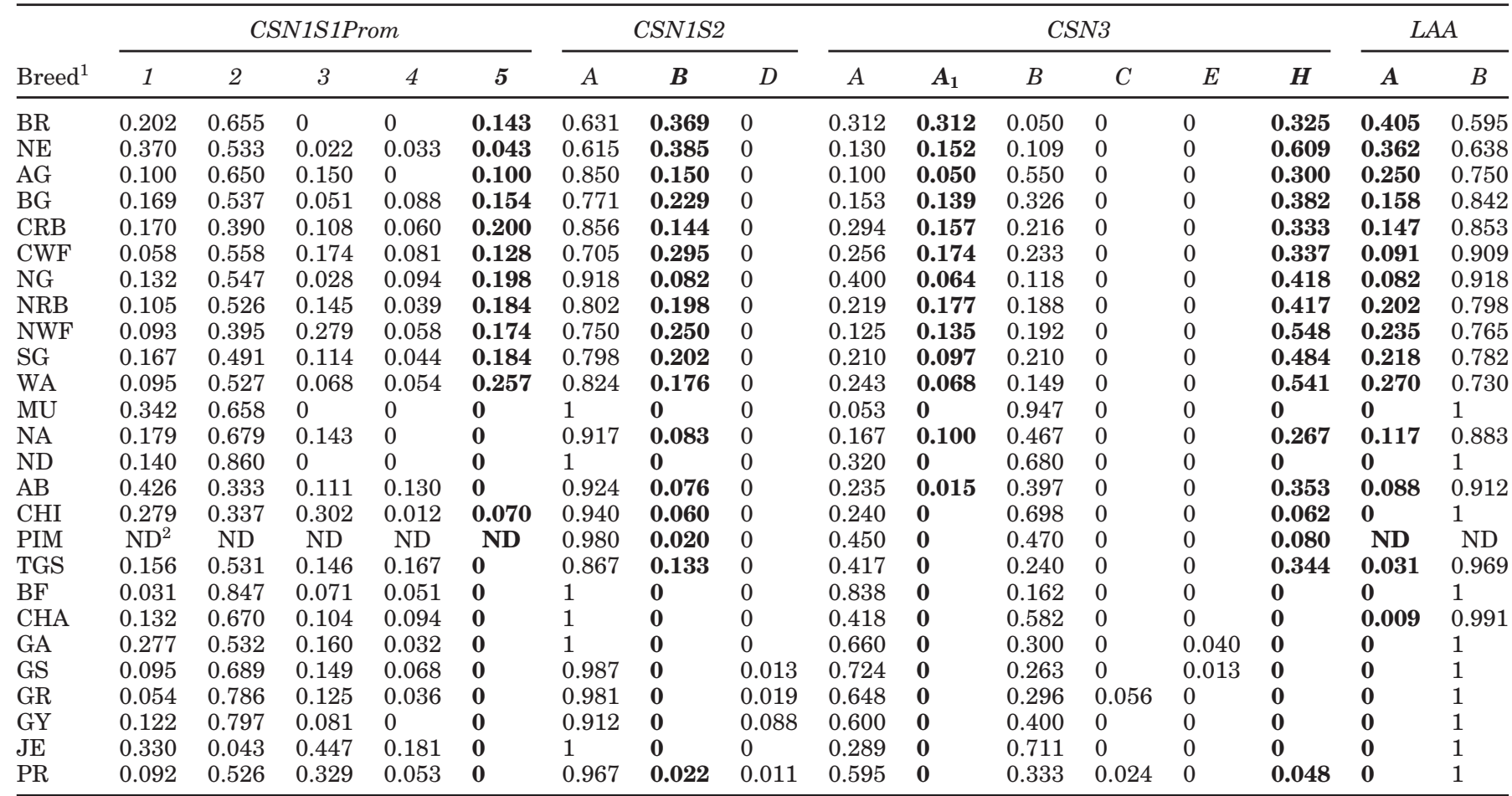

${ }^{1}$ Breed abbreviations and names as given in Table 1 .

${ }^{2} \mathrm{ND}=$ not determined.

$C S N 2 * A^{2}$ - $\left.C S N 3 * B\right)$ was common to all breeds, $1 B A A^{2} B$ to the taurines, and $1 C A A^{2} A_{1}, 2 C A A^{2} A_{1}, 2 C B A^{2} A$, $2 C B A^{2} A_{1}$, and $5 C A A^{2} H$ to zebus. Other haplotypes separated the African zebus from the Indian zebus and the taurines into 3 groups (African, central European, and southeastern European taurines). Also, several haplotypes occurred across breed groups, in particular between zebus and southeastern European taurines and African taurines. Interestingly, 5 haplotypes $\left(1 C A A^{3} H\right.$, $2 C B A^{3} H, 3 B A A^{2} H, 4 B A A^{2} H$, and $5 C B A^{2} B$ ) specific to southeastern European taurines contain the zebu-specific alleles $C S N 3{ }^{*} H$ or $C S N 1 S 2 * B$.

\section{DISCUSSION}

We report here the SNP and AA change that distinguishes the $B$ allele from other alleles at the CSN1S2 locus and also methods to identify carriers of this and other alleles at the locus. This study therefore provides necessary information that has been lacking about this locus (Farrell et al., 2004). Availability of this information will also facilitate the detection of this allele by DNA methods in individuals irrespective of age, sex, and physiological status compared with protein methods that make use of milk samples only. The identified SNP probably has an indirect effect on the physico- chemical properties of the protein variant, because it involves the conversion of the first phosphorylated serine residue into a hydrophobic amino acid (phenylalanine). This hypothesis was not addressed in this study, however. The B variant was first reported in South African zebu breeds and in the yaks (Grosclaude et al., 1976,1978 ) and is thought to be limited to these groups. In a study by Mahé et al. (1999) including 6 African $B$. taurus and indicus breeds, no polymorphism was identified at the protein level. However, Chianese et al. (1988) found this protein variant in the Italian Podolian cattle with a very low frequency but no further effort was made to characterize the AA substitutions and to include this variant in the characterization of other European breeds. Our study, besides having characterized the $C S N 1 S 2 * B$ allele, shows its wider presence, as well as of $\mathrm{CSN}^{*} \mathrm{H}$ in European breeds, mainly of southeastern origin like Chianina (Italian Podolian breed), Piemontese, Anatolian Black, and Turkish Gray Steppe, and Polish Red of central European origin. Frequencies of $C S N 1 S 2 * B$ as well as other zebu-specific milk protein alleles $\left(C S N 3^{*} A_{1}, C S N 3^{*} H\right.$, and $L A A^{*} A$ ) are highest for Nelore and Brahman, intermediate in African zebus, and lowest in all taurine breeds and are clearly related to the geographic origin of the breed, which confirms similar observations made by Beja-Per- 


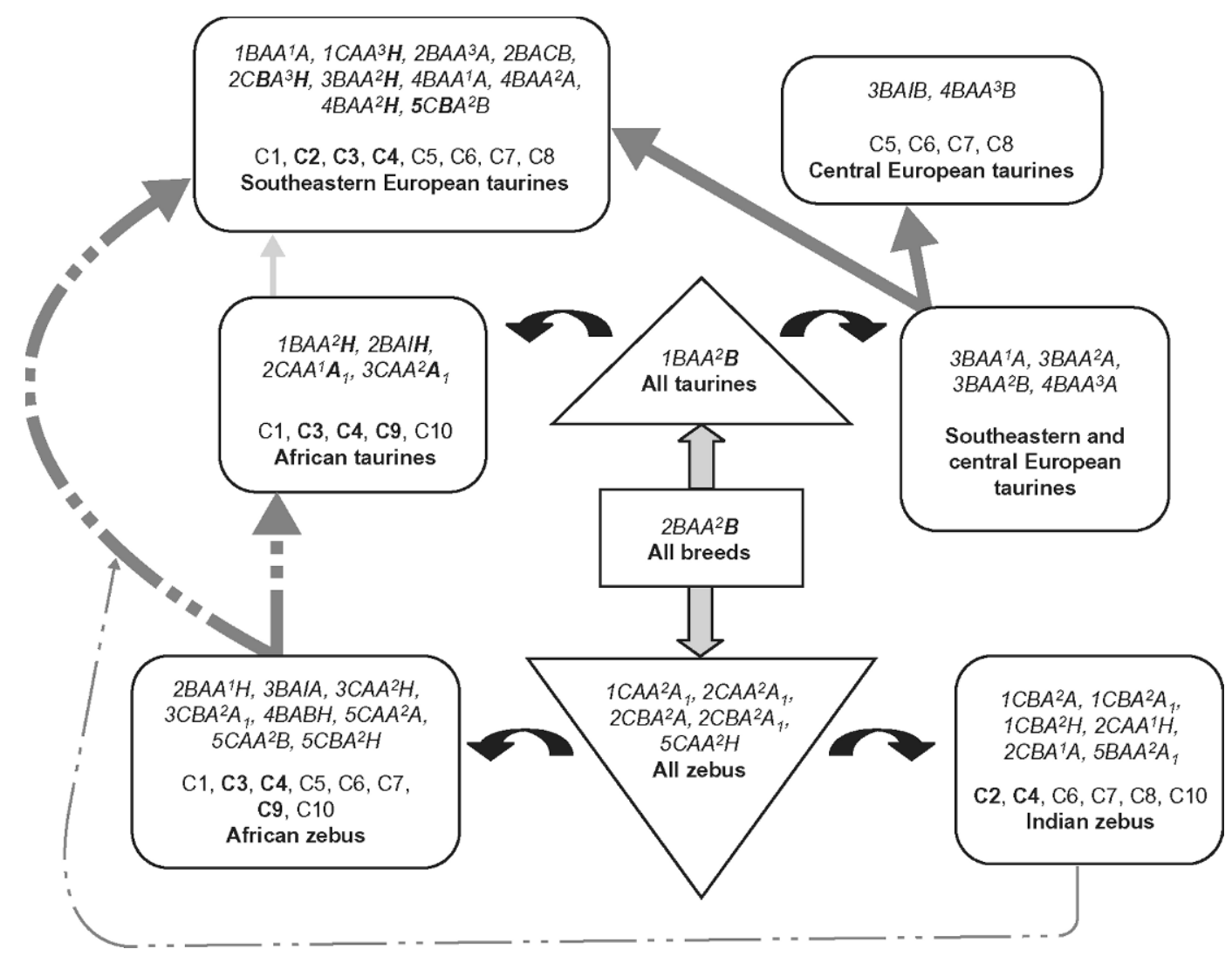

Figure 1. Common, group-specific, and intergroup haplotypes explain breed relationships, especially zebu influence on southeastern European cattle. Haplotypes were estimated with the program Phase V2.1.1 and only haplotypes with frequencies $>0.01$ are represented. $2 B A A^{2} B=C S N 1 S 1 P R O M * 2-C S N 1 S 1 * B-C S N 1 S 2 * A-C S N 2 * A^{2}-C S N 3 * B ;$ C1 to $C 10$ represent intergroup haplotypes $\left(\mathrm{C} 1=1 B A A^{1} B\right.$ and $2 C A A^{1} B ; \mathrm{C} 2=1 C A A^{2} H$ and $2 C B A^{2} H ; \mathrm{C} 3=2 B A A^{2} H ; \mathrm{C} 4=2 C A A^{2} H$ and $2 C A A^{2} H ; \mathrm{C} 5=2 B A A^{1} A$ and $3 B A A 1 B ; \mathrm{C} 6=1 C A A^{2} B ; \mathrm{C} 7=2 B A A^{1} B$ and $\left.2 B A A^{2} A ; \mathrm{C} 8=1 C A A^{2} A ; \mathrm{C} 9=2 B B A^{2} H ; \mathrm{C} 10=2 C A A^{2} B\right)$. Zebu-specific alleles that occur within southeastern European and African taurine haplotypes are highlighted; intergroup haplotypes that contain zebu-specific alleles are also highlighted.

eira et al. (2002) and Jann et al. (2004). CSN1S1Prom*5 is the zebu-specific allele that seems to have a wider distribution in African zebu than in Indian zebu breeds, which may indicate a role in adaptation to hotter climates or simply be the direct result of genetic drift.

With the exclusion of Polish Red, European breeds lacking the zebu-specific milk protein alleles are all from central Europe and are also highly specialized breeds. This fact consequently affected estimates of milk protein genetic diversities for these breeds. The low presence of these alleles in the central European breeds could be attributed to their zebu origin, or some forces of selection could have played a role. In a recent study, Jann et al. (2004) reported a significant decrease of genetic diversity in European cattle breeds from the south to the north and from the east to the west and attributed this to the process of domestication as well as natural and artificial selection. Also, high selection pressure for the milk and meat traits of central European cattle breeds may have contributed to the absence of these alleles, considering that all cattle once originated from a common ancestor. When we talk of a common ancestor, the haplotype that was common to all the breeds investigated is further proof of this. Also, all alleles within the common haplotype $\left(2 B A A^{2} B\right)$ identified in this study are considered to be the wild-type allele at their respective loci except for $C S N 3{ }^{*} B$ (Prinzenberg et al., 2003; Farrell et al., 2004; IbeaghaAwemu et al., 2005a).

Characterization of $C S N 1 S 2 * B$ and genotyping of alleles at this locus in more Bos taurus and Bos indicus cattle breeds has enabled a better definition of groupspecific CN haplotypes compared with Mahé et al. (1999). This study has identified haplotypes that occur exclusively in the various breed groups. Additionally, some intergroup haplotypes and southeastern European haplotypes containing zebu-specific alleles showed the extent of zebu gene flow into these breeds. It is evident from our work that the occurrence of more haplotypes than reported by Jann et al. (2004) and 
Ibeagha-Awemu et al. (2005a) is caused by the occurrence of $C S N 1 S 2 * B$ in African cattle and in some European cattle.

The haplotype information has further elucidated the extent of existing relationships among the breeds, particularly the zebu influence on southeastern European cattle and the Polish Red, and also the genetic subdivisions within European cattle breeds. Breed groups and intergroup haplotypes are further clues about the genetic makeup and historical development of the breeds (Mason, 1996; MacHugh et al., 1997; Troy et al., 2001; Ibeagha-Awemu et al., 2004).

Adding to our findings, Beja-Pereira et al. (2006) observed that different southern European cattle breeds were affected by introgression of breeds from northern Africa and that the previous simple hypothesis regarding the domestication process should be revised. In particular, the greater genetic diversity of the southeastern European breeds is the consequence of the presence of alleles of zebu origin and, therefore, indicates extensive hybridization with zebu cattle. Geographic proximity and early historical associations between the Mediterranean region and North Africa may explain the zebu genetic influence in southern European cattle. For example, Cymbron et al. (2005) showed that breeds in the Mediterranean region (Italy, Greece, and Portugal) had a greater frequency of zebu-associated microsatellite alleles $(6.7 \%)$ than did breeds in the rest of Europe (5.1\%). A T1 mitochondrial DNA haplotype characteristic of African breeds (Bradley et al., 1996; Troy et al., 2001) was shown by Anderung et al. (2005) to be present not only in prehistoric (1,800 yr ago) Iberian cattle but also in present-day populations, thus giving evidence of prehistoric and recent contact between African pastoralists and the Iberian Peninsula. This input from zebu cattle has also lead to increased genetic diversity of southeastern European cattle breeds and might indicate an extensive hybridization zone (Loftus et al., 1999; Jann et al., 2004; Cymbron et al., 2005) rather than reduced CN diversity of more specialized breeds by selection.

\section{ACKNOWLEDGMENTS}

This work was supported by the German Academic Exchange Service (DAAD) and in part by the European Commission (RESGEN-CT98-118). The content of this publication does not represent the views of the Commission or its services. The authors thank Christel Zörb for excellent technical support.

\section{REFERENCES}

Anderung, C., A. Bouwman, P. Persson, J. M. Carretero, A. I. Ortega, R. Elburg, C. Smith, J. L. Arsuaga, H. Ellegren, and A. Göthers- tröm. 2005. Prehistoric contacts over the straits of Gibraltar indicated by genetic analysis of Iberian Bronze Age cattle. Proc. Natl. Acad. Sci. USA 102:8431-8435.

Barroso, A., S. Dunner, and J. Cañón. 1999. A multiplex PCR-SSCP test to genotype bovine $\beta$-casein alleles $\mathrm{A} 1, \mathrm{~A} 2, \mathrm{~A} 3, \mathrm{~B}$ and $\mathrm{C}$. Anim. Genet. 30:322-324.

Beja-Pereira, A., D. Caramelli, C. Lalueza-Fox, C. Vernes, N. Ferrand, A. Casoli, F. Goyache, L. Royo, S. Conti, M. Lari, A. Martini, L. Ouragh, A. Magid, A. Atash, A. Zsolnai, P. Boscato, C. Triantaphylidis, K. Ploumi, L. Sineo, F. Mallegni, C. Taberlet, G. Erhardt, L. Sampietro, J. Bertranpetit, G. Barbujani, G. Luikart, and G. Bertorelle. 2006. The origin of European cattle: New evidence from modern and ancient DNA. Proc. Natl. Acad. Sci. USA 103:8113-8118.

Beja-Pereira, A., G. Erhardt, C. Matos, L. Gama, and D. Ferrand. 2002. Evidence for a geographical cline of casein haplotypes in Portuguese cattle breeds. Anim. Genet. 33:295-300.

Bradley, D. G., D. E. MacHugh, P. Cunnigham, and R. T. Loftus. 1996. Mitochondrial diversity and the origins of African and European cattle. Proc. Natl. Acad. Sci. USA 93:5131-5135.

Brignon, G., B. Ribadeau-Dumas, J. C. Mercier, J. P. Pelissier, and B. C. Das. 1977. Complete amino acid sequence of bovine $\alpha_{\mathrm{S}^{-}}$ casein. FEBS Lett. 76:274-279.

Ceriotti, G., D. Marletta, A. Caroli, and G. Erhardt. 2004. Milk protein loci polymorphism in taurine (Bos taurus) and zebu (Bos indicus) populations breed in hot climate. J. Anim. Breed. Genet. 121:404-415.

Chianese, L., A. Di Luccia, R. Maurielle, L. Ferrara, G. Zehender, and F. Addeo. 1988. Polimorphismo biochimico delle proteine del latte in bovine di razza Podolica. Zootec. Nutr. Anim. 14:189-197.

Cymbron, T., A. R. Freeman, I. M. Malheiro, J.-D. Vigne, and D. Bradley. 2005. Microsatellite diversity suggests different histories for Mediterranean and Northern European cattle populations. Proc. R. Soc. Lond. B. Biol. Sci. 272:1837-1843.

Erhardt, G. 1993. Allele frequencies of milk proteins in German cattle breeds and demonstration of $\alpha_{\mathrm{S} 2}$-casein variants by isoelectric focussing. Arch. Tierz. 36:145-152.

Farrell, H. M., Jr., R. Jimenez-Flores, G. T. Bleck, E. M. Brown, J. E. Butler, L. K. Creamer, C. L. Hicks, C. M. Hollar, K. F. NgKwai-Hang, and H. E. Swaisgood. 2004. Nomenclature of the proteins of cows' milk-Sixth revision. J. Dairy Sci. 87:1641-1674.

Formaggioni, P., A. Summer, M. Malacarne, and P. Mariani. 1999. Milk protein polymorphism: Detection and diffusion of the genetic variants in Bos genus. Annali della Facoltá di Medicina Veterinariy, Universitá di Parma XIX:127-165.

Groenen, M. A. M., R. J. M. Dijkhof, A. J. M. Verstege, and J. J. van der Poel. 1993. The complete sequence of the gene encoding bovine alpha s2-casein. Gene 123:187-193.

Grosclaude, F., P. Joudrier, and M. F. Mahé. 1978. Polymorphism de la caséine $\alpha \mathrm{S} 2$ bovine: Etroite liason du locus $\alpha \mathrm{S} 2-\mathrm{CN}$ avec les loci $\alpha_{\mathrm{S} 1}-\mathrm{CN}, \beta$-CN et $\kappa$-CN; mise en evidence d'une deletion dans le variant $\alpha_{\mathrm{S} 2}$-CND. Ann. Genet. Sel. Anim. 10:313-327.

Grosclaude, F., P. Joudrier, and M. F. Mahé. 1979. A genetic and biochemical analysis of a polymorphism of bovine $\alpha_{\mathrm{S2}}$-casein. J. Dairy Res. 46:211-213.

Grosclaude, F., M. F. Mahé, and J. P. Accolas. 1982. Note sur le polymorphisme génétique des lactoprotéines de bovines et de yaks Mongols. Ann. Genet. Sel. Anim. 14:545-550.

Grosclaude, F., M. F. Mahé, J. C. Mercier, J. Bonnemaire, and J. H. Theissier. 1976. Polymorphisme des lactoprotéines de Bovinés Népalais. II. Polymorphisme des caséines " $\alpha_{\mathrm{S}}$-mineures": Le locus $\alpha_{\mathrm{S} 2}$-CN est-il lié aux loci $\alpha_{\mathrm{S} 1}-\mathrm{CN}, \beta$-CN et $\kappa$-Cn? Ann. Genet. Sel. Anim. 8:481-491.

Hanotte, O., C. L. Tawah, D. G. Bradley, M. Okomo, Y. Verjee, J. Ochieng, and J. E. O. Rege. 2000. Geographic distribution and frequency of a taurine Bos taurus and an indicine Bos indicus $Y$ specific allele amongst sub-Saharan African cattle breeds. Mol. Ecol. 9:387-396.

Ibeagha-Awemu, E. M., C. O. Jann, C. Weimann, and G. Erhardt. 2004. Genetic diversity, introgression and relationships among West/Central African cattle breeds. Genet. Sel. Evol. 36:673-690. 
Ibeagha-Awemu, E. M., L. N. Nwakalor, M. N. Bemji, and G. Erhardt. $2005 \mathrm{~b}$. Genetic variability of the milk protein genes of three Cameroonian zebu breeds. Pages 9-13 in Proc. 30th Annu. Conf. Nigerian Soc. Anim. Prod., Nsukka, Nigeria. Nigerian Society for Animal Production, Ibadan, Nigeria.

Ibeagha-Awemu, E. M., E.-M. Prinzenberg, and G. Erhardt. 2005a. High variability of milk protein genes in Bos indicus cattle breeds of Cameroon and Nigeria and characterization of a new $\alpha_{\mathrm{S} 1}$ promoter allele. J. Dairy Res. 72:1-9.

Jann, O. C., E. M. Ibeagha-Awemu, C. Özbeyaz, P. Zaragoza, J. L. Williams, P. Ajmone-Marsan, J. A. Lenstra, K. Moazami-Goudarzi, and G. Erhardt. 2004. Geographic distribution of haplotype diversity at the bovine casein locus. Genet. Sel. Evol. 36:243-257.

Kumar, P., A. R. Freeman, R. T. Loftus, C. Gaillard, D. Q. Fuller, and D. G. Bradley. 2003. Admixture analysis of Asian cattle. J. Hered. 91:43-50.

Loftus, R. T., O. Ertugrul, A. H. Harba, M. A. A. El-Barody, and D. E. MacHugh. 1999. A microsatellite survey from a centre of origin: The near east. Mol. Ecol. 8:2015-2022.

MacHugh, D. E., M. D. Shriver, R. T. Loftus, P. Cunningham, and D. G. Bradley. 1997. Microsatellite DNA variation and the evolution, domestication and phylogeography of taurine and zebu cattle (Bos taurus and Bos indicus). Genetics 146:1071-1086.

Mahé, M. F., and F. Grosclaude. 1982. Polymorphisme de la caséine $\alpha \mathrm{S} 2$ des bovines: Caracterization de variant $\mathrm{C}$ du yak (Bos grunniens). Annal. Genet. Sel. Anim. 14:401-416.

Mahé, M. F., G. Miranda, R. Queval, A. Bado, P. S. Zafindrajaona, and F. Grosclaude. 1999. Genetic polymorphism of milk proteins in African Bos taurus and Bos indicus populations. Characterization of variants $\alpha_{\mathrm{S} 1}-\mathrm{Cn} \mathrm{H}$ and $\kappa$-Cn J. Genet. Sel. Evol. 31:239-253.

Mason, I. L. 1996. A World Dictionary of Livestock Breeds, Types and Varieties. 4th ed. CAB International, Wallingford, UK.

Mitra, A., Sashikanth, and B. R. Yadav. 1998. Alpha-lactalbumin polymorphism in three breeds of Indian Zebu cattle. J. Anim. Breed. Genet. 115:403-405.
Moazami-Goudarzi, K., D. M. A. Belemsaga, G. Ceriotti, D. Laloë, F. Fagbohoun, N. T. Kouagou, I. Sidibè, V. Codjia, C. Crimella, F Grosclaude, and S. M. Tourè. 2001. Caractérisation de la race bovine Somba à l'aide de marqueurs moléculaires. Rev. Elev. Med. Vet. Pays Trop. 54:129-138.

Montgomery, G. W., and J. A. Sise. 1990. Extraction of blood from sheep white blood cells. N.Z. J. Agric. Res. 33:437-441.

Nicholas, K. B., and H. B. Nikolas, Jr. 1997. GeneDoc: A tool for editing and annotating multiple sequence alignment. www.psc.edu/biomed/genedoc.

Prinzenberg, E.-M., I. Krause, and G. Erhardt. 1999. SSCP analysis at the bovine CSN3 locus discriminates six alleles corresponding to known protein variants (A, B, C, E, F, G) and three new DNA polymorphisms (H, I, A1). Anim. Biotechnol. 10:49-62.

Prinzenberg, E.-M., C. Weimann, C. Brandt, J. Bennewitz, E. Kalm, M. Schwerin, and G. Erhardt. 2003. Polymorphism of the bovine CSN1S1 promoter: Linkage mapping, intragenic haplotypes and effects on milk production traits. J. Dairy Sci. 86:2696-2705.

Raymond, M., and F. Rousset. 2001. Population genetics software and ecumenicism. J. Hered. 86:248-249. http://wbiomed.curtin.edu.au/genepop/

Stephens, M., and P. Donnelly. 2003. A comparison of Bayesian methods for haplotype reconstruction. Am. J. Hum. Genet. 73:11621169.

Stephens, M., N. J. Smith, and P. Donnelly. 2001. A new statistical method for haplotype reconstruction from population data. Am. J. Hum. Genet. 68:978-989.

Stewart, A. F., J. Bonsing, C. W. Beattie, F. Shah, I. M. Willis, and A. G. Mackinlay. 1987. Complete nucleotide sequences of bovine $\alpha_{\mathrm{S2}^{-}}$and $\beta$-casein cDNAs: Comparisons with related sequences in other species. Mol. Biol. Evol. 4:231-241.

Troy, C. S., D. E. MacHugh, J. F. Bailey, D. A. Magee, R. T. Loftus, P. Cunningham, A. T. Chamberlain, B. C. Sykes, and D. G. Bradley. 2001. Genetic evidence of Near-Eastern origins of European cattle. Nature 410:1088-1091.

Yeh, F. C., R.-C. Yang, and T. Boyle. 1999. POPGENE Version 1.31. Microsoft Windows-based freeware for population genetic analysis. http://www.ualberta.ca/ fyeh/fyeh/ 